Heredity and Evolution

By Arthur Ernest Watkins. Pp. viii $+243+2$ plates. (London: John Murray, 1935.) 7s. 6d. net.

THE recent co-ordination of experimental breeding and chromosome study has led to a complete reconstruction of our knowledge of heredity and variation. This in turn has given us the means of re-examining the mechanism of evolution and seeing the whole problem in a new light. Haldane, Fisher, Müller, Timofeeff-Ressovsky and others have taken advantage of this splendid opportunity. We therefore turn to a new book on the subject with eager anticipation.

The subject is a difficult one requiring clarity of thought and exposition as well as accuracy of information. The present work is disappointing in both these respects. After the first simple problems are dealt with, a vagueness overeasts the argument; the author does not appear to have grasped either the essential conclusions of modern genetics or the primary assumptions of Darwinism. The result is complete confusion in the treatment of selection (for example, on pp. 22, 196, 207, 215, et seq.). He mixes up self-sterility with cross-sterility as a condition of species-formation. $\mathrm{He}$ is surprised that selection will not account for the sterility of hybrids. Darwin, he says, considered that selection alone was the agent of evolution, and he concludes that Darwin was wrong. Students of evolution outside the field of genetics should know that this view would not be accepted generally by geneticists. The student will be misled by such statements as that reciprocal crosses are nearly always identical, that roses are peculiar in being permanent hybrids, and that Mendel bred sweet peas.

The book contains bibliographies, a glossary and an index. It will serve as an introduction to the general reader who wants to know what geneticists are talking about.

C. D. D.

\section{Hydrostatics and Mechanics}

By A. E. E. McKenzie. Pp. $x+272$. (Cambridge : At the University Press, 1934.) 3s. $6 d$.

THrs book, which covers the whole of the ground associated with a course up to School Certificate standard, is likely to prove unusually attractive. The author realises from his teaching experience the very true fact that "mechanics is often considered by boys as one of the dullest parts of physics", and in order to meet this difficulty he has endeavoured to sustain interest throughout by showing the bearing of the principles of mechanies on modern industrial practice in engineering, aeronauties and hydraulies. The book is notable for the number of first-class photographs of examples of these applications shown in construction and use; such instances as famous bridges, cranes, diving apparatus, turbines, Piccard's balloon, and the R. 101 may be mentioned. The style throughout is readable and the presentation interesting, and special attention is directed to familiar applications, frequently little understood, in this mechanical age. A careful selection of prob. lems and examination questions is appended to each chapter.
Songs of the Birds

By Prof. Walter Garstang. (The Week-end Library.) Revised third edition, with a New Chapter on the Classification of Birds. Pp. 139. (London: John Lane, The Bodley Head, Ltd., 1935.) 3s. 6d. net.

IN this new edition, Prof. Garstang endeavours to strengthen the scientific aspect of his subject by the inclusion of a classification of birds. Another new feature is a systematic index which is undoubtedly a boon to the reader.

The author's syllabic notation, clever though it is, would be of small use without some means of marking the rhythmic nature of the songs. This he has given by incorporating the sounds in verses, some of them representing imaginary conversations between two songsters, a pleasant device for the non-scientific reader. The reviewer finds the songs, as thus transcribed, generally recognisable by one familiar with them-no mean achievement.

It is on the scientific side of the little book that we encounter difficultios. Prof. Garstang implies that the syllabic notation of birds' song may be used as a serious contribution to taxonomic zoology. The example he cites - the willow warblers, true warblers and whitethroats-fails to convince the reviewer. The difficulty of getting observers of uniform ' $r e$ ception' for these sounds would of itself render the method unfitted for strictly scientific purposes. Prof. Garstang does not take much notice of the imitation factor in the songs of birds, or of the individual differences, which are considerable. An immense number of mechanical records, showing the variations in the songs of each species, possible seasonal variations and so forth, would seem to afford the only means of putting the study of bird music on a scientific basis. Meanwhile, let us be grateful for the author's help in the æsthetic appreciation of songs of birds.

Lehrbuch der angewandten Geophysik (Geophysikalische Aufschlussmethoden)

Von Prof. Dr. Hans Haalek. Pp. vii $+376+6$ plates. (Berlin: Gebrüder Borntraeger, 1934.) 24 gold marks.

THIs book is intended to serve as an introductory textbook, of not too difficult character, covering the whole field of applied geophysics in a systematic manner, for the use of students-physicists, geologists, mining engineers, surveyors - who desire to be acquainted with this important branch of science. It is written from a definitely practical point of view and with practical aims, and theoretical development and proofs of formulæ are kept within narrow limits. It is about equally divided between the gravimetric, magnetic, electric and seismic methods ; in each case an account is given of the physical principles under. lying the method, the instruments used and the way in which they are employed, the method of reducing the observations and making deductions from them, with practical examples and a description of typical surveys and results obtained, with references. The book well serves its purpose as a comprehensive introductory textbook. 